Historic, Archive Document

Do not assume content reflects current scientific knowledge, policies, or practices. 



\section{JOSEPH F. MARTIN}

\section{Perennial Nurseries \\ P A I N ES V I L L E, O H I O
LI 9 F R P

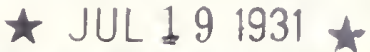

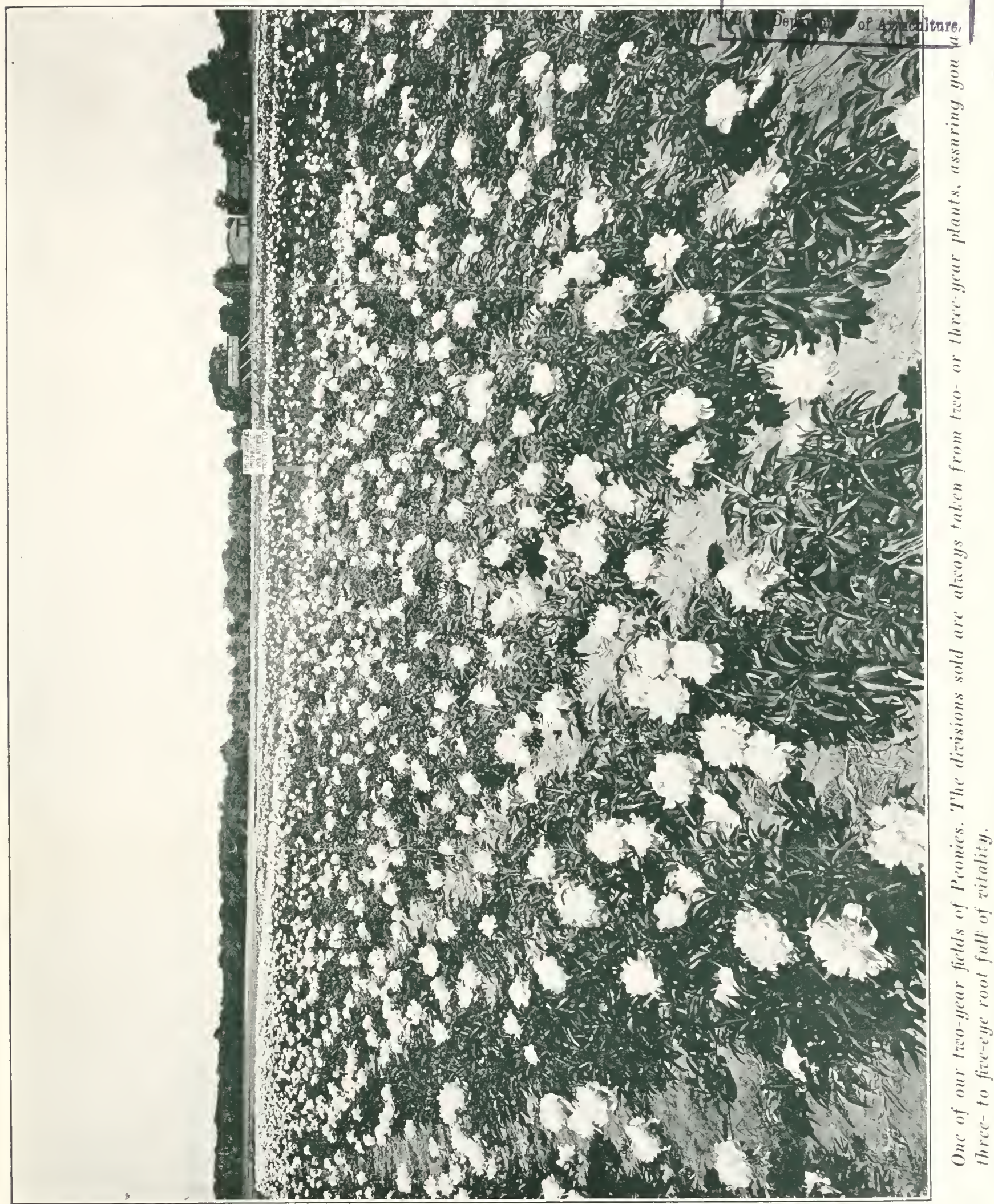




\section{PEONIES}

Immediately after first of September, we will move our entire stock of Peonies. Our divisions are made for sale and for our own plantings. The varieties listed herewith, we have in good quantities and are able to offer same to our customers at the following reasonable prices. By checking over the list, you will find that we have the outstanding standard sorts and also the best of the exhibition types.

In making your purchases, we ask that you take into consideration our methods of production. Our fields are worked from early Spring until the plants are ready for transplanting. They are highly cultivated throughout the season which assures you of receiving roots well developed and should give a maximum amount of flowers after planting.

Please note the field shown on the cover are two-year plants showing good healthy growth and also a fine crop of flowers. Every root shipped is guarantecd true to name. We will either replace the plants or refund the price paid if any are found not true.

$$
\begin{array}{cc}
\text { PeT Per } \\
10 & 100
\end{array}
$$

ILH ATRE. Plle white with a fow pencilings of carmine on the edge of center petals. Fragrant. 2.0018 .00

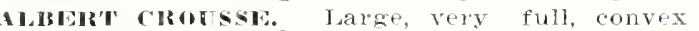
blooms of soft shell-pink.

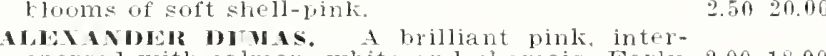

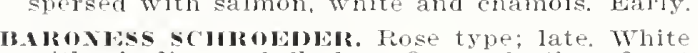
with shadings of flesh. One of the finest Peonies.

2.0018 .00

HAlLS MCKILLIP. Clown type; midseason.

The irregulal rich cimson petals of the center.

are mingled with gold stamens.

CILSTIN GrWWI. Crown type; late midseason. The broad outer petals are silvely pink. 1.0035 .00

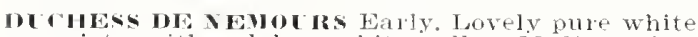
variety with sulphur-white collar. Medium size: fragloint

FuILIS stPIRIB. Tery large, loose, crown-type flower; gualds and center of deep mauve-pilik petals and a scant collar of narrow light lilac petals.

IETIXIA VIRIMIR. Tery beautiful, cup-shaped flower; flesh-pink, with collar shaded yellow and salmon, outer guard petals lilac-white.

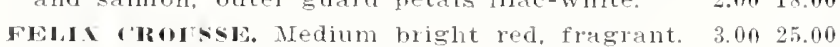
FISAI I MAMI. Early, pure white with crimson markings in the center.

Fuom, TIRAs IRE. Mid-season, pink, Old favorite cut flower variety.

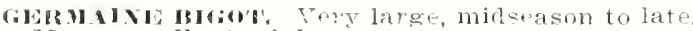
Most excellent pink.
G.IVIS Dorr. Soft pink intermingled with

JE.INI D.Mrc. Soft pink intermingled with
sulphur-white and rose. Center spotted carmine.

JiHLdic. Rose type: midseason. Buds show delicate opal tints; as they unfold the color changes to ivory-white.

KAIR hOSENFIEID. Pure, rich, intense crimson. of nalt-rose type; it makcs and remains a splendid full rounded flower of excellent substance.

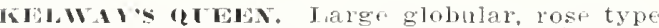
blooms: center high. buit and cupped. Nallyelose with tinting of calmine-pink.

L. ILE. Tery large globular flowers. Guards

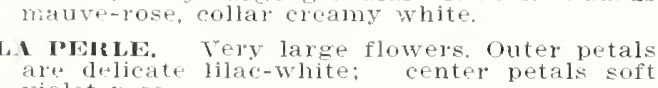
violet-rose.

M Mals. Wonderful flower of pures
Pelfect rose type, large and globular.

LONGENGLaW. Brightest crimson with a cherry tone. The flower is high, compact, semi-rose form.

IMIy cromssis. Uniform pure white, with the conter petals occasionally flecked crim-

IIRIS CIOHESE. Color sort salmon-pink shaderl a clossy satiny-lilac. Bomb type; midseason.

2.0018 .00

2.0018 .00

$2.50 \quad 20.00$

2.0018 .00

$3.00 \quad 25.00$

$2.50 \quad 20.00$

$5.00 \quad 40.00$

$3.50 \quad 30.00$

$30.00 \quad 225.00$ $10.00 \quad 85.00$

$3.50 \quad 30.00$

40.00300 .00

$8.00 \quad 75.00$

$2.50 \quad 20.00$

$5.00 \quad 40.00$

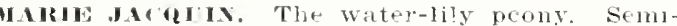
double, cup-shaped white flowers. $3.00 \quad 25.00$

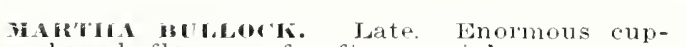
shaped flowers of soft rose-pink. $15.00 \quad 125.00$ MIIY IRINI. Midseason Peony of a rich deep red, most distinct.

MIL'OX III. Rose type; late. Flowers large, clipped; cleal soft flesh color.

MvE. JCCL1. Pink of mediun shade with IoIs'IE GICIIX. Light solferino-red that comes in early midseason. Fragrant.

Moxs MIIONI. Tery large cup-shaded flower, ivory white center petals splashed with carmine.

Mors JLES ELIE. Color an ideal glossy lilac-pink. shading to a deeper rose at the base.

$4.50 \quad 40.00$ $8.00 \quad 75.00$ $3.00 \quad 25.00$ $2.50 \quad 20.00$ $3.00 \quad 25.00$ $4.00 \quad 35.00$

MoNs Haridx CuHzac. Semi-rose type. Midseason deep maloon with garuet hues and bril liant black lustre.

10.0080 .00

MII. AIGUS' DHSSIRT. Uniform violet-rose with gualds and center" malked with carmine.

$4.50 \quad 40.00$

HuL. Culdi. General color is pale hydrangea-pink, shaded darker toward the center. Rially bloomer.

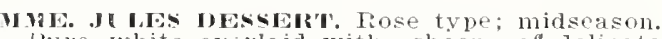
Pule white overlaid with sheen of delicate blush, pink center.

PHilondeLE: Primary petals bright violet-rose; center of golden-yellow petals changing to cream or amber yellow.

$12.50 \quad 100.00$

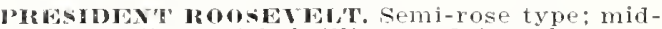
season. Deep rich brilliant red in color:

PIMWVIRE. Outer petals sulphur-white, conter petals deep sulphur-yellow. liest yellow Peony. 10.00

IR Fu) DRAGox. Single, large brilliant crimson 20.00125 .00

IRING IIOI'TENs. Semi-lose type flower. is unitorm hydrangea-pink; guards and center petals marlied carmine.

$3.50 \quad 30.00$

IRIHARI CARVIL. Triform bright crimson;

fragrance pleasing. Free bloomer. $\quad 10.00 \quad 90.00$

SIr II MErRMURD'T. Apple blossom pink with each petal silver tipped. Semi-rose type;
midseason.

SINGLE FI I.JO. Darle maroon with velvety, ous petaloids striped crimson and white 30.00200 .00

GOIV. Wr CHAs. Gombatu' Tricolor, rose pink with creain collar, midseason.

TIUdics Color rich satiny pink with glossy reflex. Flowers are enormous in size of full rose type.

$10.00 \quad 75.00$

CMHEI. C'A Roses. Rose type; very early. Guards laid with delicate salmon and LeFrance pink tints.

$2.50 \quad 20.00$

WMAER FAxox. Color is soft coral-pink, shaded lighter at the ends of the petals and $10.00 \quad 90.00$ 


\section{IRIS GERMANICA}

\section{German Iris}

From the second week of July on, we consicker the best time to transplant Iris Germanica. We have found that the tops are well ripened and the roots can be noved and transplanted with very good results. If planted at this time, the plants will immediately start making a new growth and the following spring they will flower ahmost to perfection. You will gain an entire year on the production.

We heheve we lave a list of varieties which will cover the outstanding sorts such as Anulussadeur, Iord of June, Gold Imperial and other varieties equally an good. 'Tle older varieties we are histing ane the sorts that are maintained in cultivation because of their heauty and will rearlily sell, either for catalog work or for all sorts of resale purposes. We ask that you kindly take time and check over our list. We always ship plants of gook quality.

$\begin{array}{cc}10 & 106\end{array}$

ArNElacilow. Large flowers of soft rayish lavender shading to rich yellow through the center.

Alcosar. S light, bluish violet; F. deep purple with bronze veined throat. Striking flower.

AMRssurLr. S. a fascinating smoky velvety purple color; F. velvety purple-maroon; beilds and style yellow.

Arrirsecte. Fragrant. An unusually rich coloring, the standards being rich purple violet and the falls deep velvety plum purple.

AsI. S. pale silvery larender deepening at base to golden yellow. F. flaring, pale red-purple. lighter toward margin.

CAPICL. A self-colored flower with standalds phlox-purple and falls slightly deper in color, shading to bluish white at the haft

Colrand. splendid lall pallida. Flower's medium dark blue. A fine landscape variety.

CIIssev1r. Tallest and best yellow Iris, with bright Prussian red veining at the throat. "

DRF. Y. 36 inches. S and $F$ soft cleal pink. A beatiful lris of Tallida type.

EIboruno. s. fiery opaleseent: F. old gold splashed burnt purple.

GIFFIx. A latre flower with bright riolet stin dards and rich velvety violet purple falls.

IDAHERINE FIR Fin. S. clear sulphur yellow. F velvety violet-camine. Orange beard

GOLD MIPIIIL. A yellow solf of wonderful, bright clear coloring. S. and F. Empire to lemonchrome-yellow throughout.

IMPIR I'TOR. S. very large clear violet. F, beautiful shade of reddish-violet reticulated redbrown at the throat.

Isol.INI. Standalds lilac-pink; falls deep lilacpink veinerl brown at base. Orange beard.

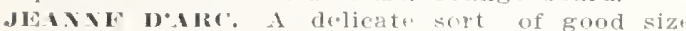
and form; white with edges partly checked and

JI IdI. A clear blu violet self with blight orange beard.

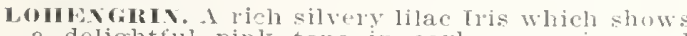
a delightfui pink tone in early morning and again in late afternoon.

MORI OF ILIE., s. very bload and flopps, light chicory-blue; 1 . drooping, lavenderwiolet. Haft marked with widely spaced reticulations of old gold.

LoI:EL. Perfect-shaped flowers, falls of a deep ultra-niarine blue, more or less vcined with creamy-white and boldered sulphur-yellow,
making a beautiful contract.

MAGXIFIC. S, light violet blue on white. F. long drooping, rep reddisl violet reticulated brown. MIS. MILIV GIRIV. Beautiful rosy mauve.

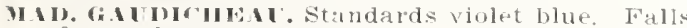
a deep velvety purple. One of the most beautiful.

MANIML CIOH.IT. Standards are cream shaded buff and pink, and tintect lilac at the edges, While the falls are white. reticulated violet at the edge.

LEN'I WILLAMsox. Campanula violet and velvety royal purple. Brilliant gold beald. Massive in growth and flower.

MIs. II. DARWIV. Pure white. F. slightly reticulated violet at the base; very beautiful Hejght, 2 ft.

\section{$.60 \quad 5.00$}

$60 \quad 5.00$

1.5012 .00

$60 \quad 5.00$

$2.50 \quad 20.00$

$.60 \quad 5.00$

1.5010 .00

$2.00 \quad 15.00$

2.0015 .00

$.60 \quad 5.00$

.807 .00

(i) 5.00

$2.00 \quad 15.00$

$1.50 \quad 12.00$

1.0108 .00

$.60 \quad 5.00$

$.60 \quad 5.00$

$.60 \quad 5.00$

$.00 \quad 8.00$

$.60 \quad 5.00$

$2.00 \quad 15.00$

$60 \quad 5.00$

$2.00 \quad 15.00$

$.60 \quad 5.00$

$.60 \quad 5.00$
$60 \quad 5.00$
$I^{3}+10+100$

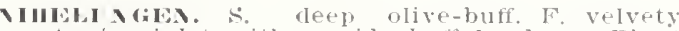
petunia-violet with a wide huff border: Plant growth is most vigorous and flowers ar. borne in

OPLI? In intensely bright violot-red bicolor of distinctive rich iont. S. livid purple l. $v+y^{*}$ dusky anticula-purpl

Plosplare. s. bright larender blue. F. weIl rounded deep red-purple. lighter at margin, brown reticulations, orange heard. at malein,

l'ilvisosic. A very handsome flower of fine form. The standards ale a decipyellow, falis lighter.

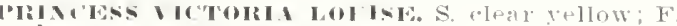
plum.

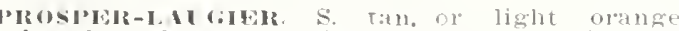
bearl. A frorte With most pvervone Robust grower, and very free flowering.

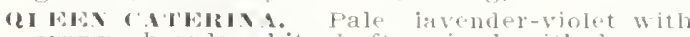
orange beard: White laft, weined with bronze. A strong grower.

RLdiv. Large flowers. Violet stanclads. Igerat fum blue falls, lyarker in the renter.

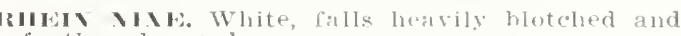
feathered purple.

swrinos. S. hright amparo-purple; $F^{2}$ velrety raisin-purple. lisard conspicuous bright orange
one of the briglatest Irises in the garden.

slilis ill. A delightful shade of pale vellow sharling to amber in the throat. With a lemon colored beard.

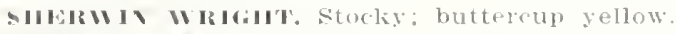

SLIX Rusis. A rich rose-pink self with a delicate purplish sheen. Free flowering, vigorous II I IIIM. A lovely plicata, white with the

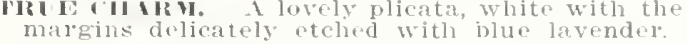
VIII: IILIIIII'. Pure white edged with desep rose. Flowers of perfect form.

(1) IN I: IUY. S. smoky lavender shaded yellow. F. blue and gold, with orange beard. A healutiful free flowering blend of rare form and finisl

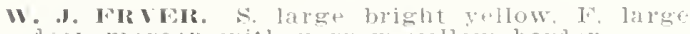
deef maloon with latrow yellow border.

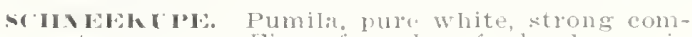
pact growt. Fine for dwalt border or in

\section{IRIS SIBERICA}

mIIIRIC. The flown resumbling the spanish and English Iris. Thess make a bright show in the galden and excellent fol cutting. Purplixhblue flowers, blooming from latte part of $\lambda$ lay until ent of Juomi

slibiric I Iar. Pure white. 3 fect

elops the largest blooms of This variety devglomp

I'IRIR': IILIS. Sky, china blue and white. The blue efeet of the plantina find many ate. The IPEINACOII $\mathrm{S}$. 36 to 48 inches. This is a particularly valuable species for sereritl rasons. Rich yellow color: will grow in marsh or swampy land even with two or thre inches of water over it. It is an English species. Will also
grow in dry soil.
150500

$1.00 \quad 8.00$

iin 500

$60 \quad 5.00$

$1.00 \quad 8.00$

$00 \quad 8.00$

$3.00 \quad 25.00$

$150 \quad 12.00$ 1.5012 .00

$60 \quad 5.00$ $50 \quad 10.06$ 0008.00 $.00 \quad 7.00$ 1. 


\title{
IRIS KAEMPFERI
}

\author{
Japan Iris
}

'This family of plants always are a specialty with us. Annually, we grow extra large quantities of the various sorts and again, we are calling your attention to our list. We have every reason to believe that our customer have found our generous divisions satisfactory, also our varieties. The fact is proven by the large quantities annually sold.

Please check over on list carefully: whatever variety you may seleet, we are sure will give you satisfaction for we do not grow any of the inferior sorts. We will be very glad to receive your favors from now until late Fall. The first of September we will start shipping. Therefore, if you wish to assure rourself of receiving the varieties, in which you are interested, we advise that you place your order early, so that we can make reservations for you.

ASTAR'TE. Double beautifil dark violet 1.5010 .00

Glikl-Nu-NMI. Glistening white, creamy

white etigmas.

riched by a creany glow from the gold banded

centel.

rugrcule. Double, clear lilac, blue. petaloids tipped white

petaloids tipped violet. Enormous double
flowers.

IAGMRIH. A very beautiful all lavender flower fxcept a yellow spot in the center of cach of its six p tals. An exceptionally well formed flower. 2.0015 .00

KUML FINGIN. (Excited Bear). F. purple-blue stigmas lighter, long olunge bars, six petals,

very tall grower.

bloom. Purple mahogany-red. 1.5010 .00

HELPOMEvi: Double soft blue distinctly veined

with dark blut.

NEPTINE. 3 petal strong glowing variety re-

sembling malogany in color.

PuTrocis. Single, superb dark violet.
1.5010 .00

$50 \quad 3.0 .00$ $50 \quad 10.00$ $\begin{array}{cc}\text { Per } & \text { Per } \\ 10 & 100\end{array}$

1.5010 .00

'HosminRPNa. Single bright rich blue produced by sanding of velrety blue on white. IBINE DES IILGAMES. Deep blue shading with
age to light blue with white veins.

SICISx. In bud extra heavy. Pule white with cream stignias. Gold banded center. six petalcd banded center. six petaled ki-No-royo. Double blue and white. $\quad 1.5010 .00$

'OKIO-No-MorI. Early flowering, glistening white ereamy white stigmas enriched with dep gold banded centers. 6 pctals. $2.00 \quad 15.00$

GCHI. Beauriful six-petaled flowers. Cerulean blue with golden center and white.

WILLIM TEL. Cream white interningled with lilac, loep gold banded center. lavender stigmas outstanding in the list of new varietics.

WAmL IHO'Tr. Large lavender blue with primrose blotches, surrounded by light blue halo and radiating into dark veins petaloid stigmas dark blue. Six extra large petals to the flower. 3.0025 .00

IEZONISHIMA. Falls red-lavender shaded purple, and beautifully veined white, yellow blotch in center, three-petal flower. $2.00 \quad 15.00$ 